\section{Peran Academic, Social dan Environment Support pada Intensi Berwirausaha M ahasiswa}

\section{Fauzani, Suryani*, Rahmawati}

Fakultas Ekonomi dan Bisnis Islam, IAIN Lhokseumawe, Indonesia

\begin{abstract}
A bstract
Purpose- This study aims to analyze the factors that influence the level of student interest in entrepreneurship in terms of contextual namely academic, social and environmental support. Methods- Data was collected through the distribution of questionnaires to 100 students consisting of Islamic Economics and Business Faculty students, and the hypothesis was tested by multiple linear regression. Findings- The students' entrepreneurial intentions to create a business are largely determined primarily from the environment, social and academic support. Implications- This study offers alternative recommendations to universities and policymakers about the entrepreneurial intentions of business students.
\end{abstract}

Keywords: academic support, social support, environment, entrepreneurship intention

\begin{abstract}
A bstrak
Tujuan- penelitian bertujuan untuk untuk menganalisis faktor-faktor yang mempengaruhi tingkat ketertarikan mahasiswa dalam berwirausaha. Metode- Data dikumpulkan melalui penyebaran kuesioner pada 100 mahasiswa yang terdiri dari mahasiswa Fakultas Ekonomi dan Bisnis Islam, dan hipotesis diuji dengan regresi liner berganda. Hasil- Hasil penelitian menunjukkan bahwa niat kewirausahaan mahasiswa untuk menciptakan bisnis sangat ditentukan terutama dari lingkungan, dukungan sosial dan akademik. ImplikasiPenelitian ini berkontribusi pada literatur mengenai determinan niat wirausaha. Studi ini menawarkan rekomendasi alternatif kepada pihak universitas dan pembuat kebijakan tentang niat kewirausahaan mahasiswa bisnis.
\end{abstract}

Keyword: dukungan akademik, dukungan sosial, Lingkungan, berwirausaha

Pedoman Sitasi: Fauzani, F., Suryani, S, \& Rachmawati, R. (2019). Peran Academic, Social dan Environment Support pada Intensi Berwirausaha Mahasiswa. SERAMBI: Jurnal Ekonomi Manajemen dan Bisnis Islam, 1(3), 111 - 118

D 0I: https:/ / doi.org/ 10.36407/ serambi.v1i3.133

\section{SERAM BI}

Received 15 Nov 2019

Revised 15 Dec 2019

Accepted 28 Dec 2019

Online first 30 Dec 2019

\section{Paper type}

Research paper

Email korespondensi:

suryapijar@yahoo.com

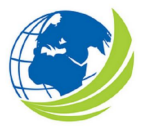

SERAMBI: Jurnal Ekonomi dan Bisnis Islam, Vol 1, No.3, 2019, pp. 111-118 elSSN2685-9904 


\section{Pendahuluan}

Revolusi industri 4.0 tidak hanya menyediakan peluang, tetapi juga tantangan bagi generasi milineal yang tidak mengikuti perkembangan teknologi. karena dalam situasi ini banyak peluang-peluang dari canggihnya teknologi yang dapat mempermudah akses dalam segala sektor kehidupan. Layanan menjadi lebih cepat dan efesien serta memiliki jangkauan koneksi yang lebih luas dengan sistem online banyak kemudahan dan inovasi yang diperoleh dengan adanya dukungan teknologi digital. Berbagai kemudahan yang diberikan oleh kemajuan teknologi tidak akan menjadi bernilai ekonomi jika tidak didukung oleh keterampilan masyarakat Indonesia untuk memanfaatkan itu semua menjadi sebuah peluang. Seperti diketahui, tingkat kewirausahaan Indonesia masih sangat rendah yaitu di peringkat 94 dari 137 negara berdasarkan Iaporan Global Enterpreneurship Index tahun 2018. Bahkan Indonesia berada di bawah negara-negara ASEAN Iain seperti Singapura (27), Malaysia (58), Thailand (71) dan Philipina (84). Kondisi ini menjadikan tantangan tersendiri bagi pemerintah dan institusi pendidikan untuk lebih berperan aktif mendorong minat wirausaha di kalangan anak-anak muda, termasuk mahasiswa.

Pentingnya kewirausahaan bagi masyarakat telah diidentifikasi dan dibahas sejak abad ke lima belas, dan diskusi itu tetap menjadi perhatian sampai sekarang (Kirchhoff et al., 2013; Maresch et al., 2016). Pertanyaan yang sering muncul adalah apa dan bagaimana keterampilan dan kompetensi wirausaha dapat dipupuk selama pendidikan. Dari akar sejarah ini, pendidikan kewirausahaan kemudian berkembang menjadi menjadi bidang yang menonjol. Bidang ini lahir dari beragam disiplin ilmu, yang meliputi ekonomi, manajemen, pendidikan, dan studi teknis (Maresch et al., 2016). Perguruan tinggi merupakan pilar penting dalam mendorong kemajuan bangsa, termasuk mendorong kreativitas dan pengetahuan mahasiswa untuk dapat menerapkan ilmu nya di tatanan praktis. Seluruh perguruan tinggi bertujuan untuk mendorong pengembangan sosial dan ekonomi di sekitarnya melalui pendidikan dan pelatihan untuk penciptaan peluang usaha dan pengembangan kewirausahaan; mempublikasikan berbagai karya ilmiah, dan sekaligus menciptakan tenaga kerja yang memiliki pengetahuan dan keterampilan yang dapat disesuaikan dengan perkembangan zaman, termasuk era revolusi industry 4.0 seperti sekarang.

Beberapa peneliti memberikan perhatian pada pentingnya motivasi untuk menjalankan bisnis dan karena itu mempertanyakan apakah pengajaran dapat memungkinkan motivasi ini muncul (Colette, Hill, \& Leitch, 2005); yang lain, sementara itu, percaya bahwa motivasi kewirausahaan ini dapat dikembangkan dengan pendidikan kewirausahaan khusus (Souitaris, Zerbinati, \& Al-Lahman, 2007). Beberapa studi memberikan hasil yang berbeda-beda terkait dengan pendidikan wirausaha di instansi pemerintah. Beberapa peneliti menyebutkan dampak positif dari pendidikan kewirausahaan (misalnya, Block et al., 2013, Souitaris et al., 2007, Walter dan Dohse, 2012), sedangkan yang lain menemukan bukti bahwa efeknya secara statistik tidak signifikan atau bahkan negatif (misalnya , Oosterbeek et al., 2010, von Graevenitz et al., 2010), dan niat wirausaha berbeda berdasarkan gender (Westhead \& Solesvik, 2016). Studi yang lebih baru dilakukan oleh Barba-Sánchez dan Atienza-Sahuquillo (2018) yang mengidentifikasi bahwa kebutuhan akan kemandirian adalah faktor kunci dalam niat wirausaha para mahasiswa dan mengkonfirmasi kontribusi positif yang dimiliki pendidikan kewirausahaan terhadap niat wirausaha mereka.

Penelitian yang dilakukan di Indonesia mengidentifikasi tiga faktor utama yang dapat mempengaruhi niat wirausaha mahasiswa, yaitu demografi (Azwar, 2013); sikap (Azwar, 2013; Suharti, \& Sirine, 2012 ), dan kontektual termasuk academic, social dan environment support 
Fauzani, F \& Suryani, S., N iat wirausaha, dukungan akademik, sosial dan lingkungan...

(Azwar, 2013; Suharti, \& Sirine, 2012), dan Rahmah (2017) menempatkan social support sebagai pemoderasi. Terkait dengan kontekstual, hasil berbeda ditemukan antara penelitian Azwar (2013) yang tidak berhasil membuktikan efek signifikan academic support dan environment support, sedangkan Suharti dan Sirine (2012) menemukan hasil sebaliknya. Dapat dinyatakan bahwa faktor kontekstual masih belum secara meyakinkan menjadi predictor niat wirausaha sehingga upaya untuk menguji ulang hubungan tersebut masih terbuka.

Dalam konteks ini, pertanyaan yang diajukan adalah: apakah faktor academic support, social support, dan lingkungan dapat mempengaruhi niat wirausaha yang dimiliki mahasiswa?. Dari sudut pandang ini, maka tujuan utama dari penelitian ini adalah untuk menganalisis dampak academic support, social support, dan lingkungan terhadap niat wirausaha di kalangan mahasiswa. Tujuan utama kedua dari penelitian ini adalah untuk mengatasi kesenjangan penelitian sebelumnya yang masih memberikan kesimpulan yang berbeda mengenai faktor yang mempengaruhi niat wirausaha mahasiswa dari sisi kontekstual. Oleh karena itu, penelitian ini dapat berkontribusi dari sisi praktis untuk pengelola pendidikan, dan bukti empiris terbaru mengenai peran faktor kontekstual terhadap niat wirausaha.

\section{Kajian Teori dan Pengembangan Hipotesis}

Minat wirausaha merupakan keyakinan yang diakui sendiri oleh seseorang yang mereka bermaksud untuk mendirikan usaha bisnis baru dan secara sadar berencana untuk melakukannya di beberapa titik di masa depan (Thompson, 2009, dalam Maresch et al., 2016). Minat untuk berwirausaha telah menjadi perhatian para peneliti bidang perilaku dan kewirausahaan, karena minat atau niat telah membuktikan prediktor terbaik dari perilaku yang direncanakan, terutama ketika perilaku sulit untuk diamati, atau melibatkan jeda waktu yang tidak terduga. Baru-baru ini, sebuah studi longitudinal oleh Kautonen et al. (2015) menegaskan bahwa minat wirausaha memprediksi tindakan kewirausahaan. Dengan demikian, pertanyaan tentang apa yang mempengaruhi minat wirausaha adalah yang relevan untuk pembuat kebijakan, praktisi, dan pendidik (Maresch et al., 2016).

Penelitian tentang peran faktor konteksutal dalam pembentukan niat wirausaha didasarkan dari Theory of Planned Behavior (TPB) dari Ajzen (1991). Dalam teori ini, perilaku masa depan seseorang didahului oleh niat: semakin kuat a niat seseorang untuk terlibat dalam perilaku tertentu, semakin besar kemungkinannya bahwa perilaku yang sebenarnya akan dilakukan. Selanjutnya niat untuk melakukan perilaku yang diberikan adalah hasil dari tiga anteseden kognitif: (i) sikap terhadap perilaku; (ii) norma subyektif; dan (iii) kontrol perilaku yang dirasakan.

Model yang yang menggabungkan unsur personal dan lingkungan ini dikenal dengan Luthje and Franke's model (LFM). Dalam model LFM, faktor lingkungan dianggap sebagai "pengisi celah" penting dalam hubungan antara kepribadian individu dan niat wirausaha mereka (Luthje dan Franke, 2003). Penelitian sebelumnya telah mempertimbangkan berbagai faktor lingkungan dalam kaitannya dengan niat kewirausahaan individu., beberapa faktor kontekstual yang mendapatkan perhatian adalah academic support, social support dan environtment support (Franke dan Lu'thje, 2004; Smith, Collins dan Hannon, 2006; Azwar, 2013; Suharti, \& Sirine, 2012; Saeed et. Al., 2015; Mustafa et al., 2017; Rahmah, 2017).

\section{H ubungan academic, sosocial, environment support dan niat berwirausaha}

Para peneliti sebelumnya telah mengakui bahwa untuk berhasil mendorong niat kewirausahaan individu, program pendidikan kewirausahaan idealnya harus tertanam di seluruh kurikulum 
universitas (Smith, Collins dan Hannon, 2006). Saeed et al. (2015) dalam studinya menunjukkan bahwa persepsi positif siswa tentang lingkungan universitas mereka dapat meningkatkan selfefficacy kewirausahaan mereka sehingga mempengaruhi niat kewirausahaan mereka. Lingkungan universitas yang mendukung kewirausahaan dapat memberikan siswa pengetahuan, keterampilan, atau teknik bisnis yang diperlukan untuk memungkinkan mereka memanfaatkan impian wirausaha mereka, melalui beberapa cara. Pertama, melalui berbagai program pendidikan, universitas dapat membekali siswa dengan pengetahuan, keterampilan, dan kesempatan magang dan jejaring yang diperlukan untuk memajukan ide-ide embrionik siswa ke dal am konsep yang dapat diterapkan (Saeed et. AI., 2015).

Studi lain yang dilakukan oleh Mustikawati dan Bachtiar (2008) menunjukkan secara empiris apakah ada hubungan antara dukungan masyarakat dan niat kewirausahaan siswa kejuruan. Hasil penelitian mereka menunjukkan pengaruh positif yang signifikan dari dukungan sosial pada niat kewirausahaan di kalangan siswa kejuruan. Hasil penelitian ini menunjukkan bahwa semakin besar dukungan sosial yang diberikan oleh orang tua dan semakin besar masyarakat kepada kaum muda, semakin besar minat siswa SMK untuk terlibat dalam berwirausaha. Studi oleh Suharti dan Sirine (2012) juga menemukan bahwa dukungan akademik dan dukungan sosial, meningkatkan niat kewirausahaan di kalangan siswa. Dukungan universitas juga ditemukan memiliki pengaruh signifikan terhadap niat wirausaha (Mustafa et al., 2016) dan juga dipengaruhi oleh dukungan pendidikan dan relasional (Gelaidan \& Abdullateef, 2017). Berdasarkan penjelasan di atas maka hipotesis yang diajukan adalah:

$\mathrm{H}_{1}$ : academic support berhubungan signifikan dengan niat wirausaha

$\mathrm{H}_{2}$ : social support berhubungan signifikan dengan niat wirausaha

$\mathrm{H}_{3}$ : environment support berhubungan signifikan dengan niat wirausaha

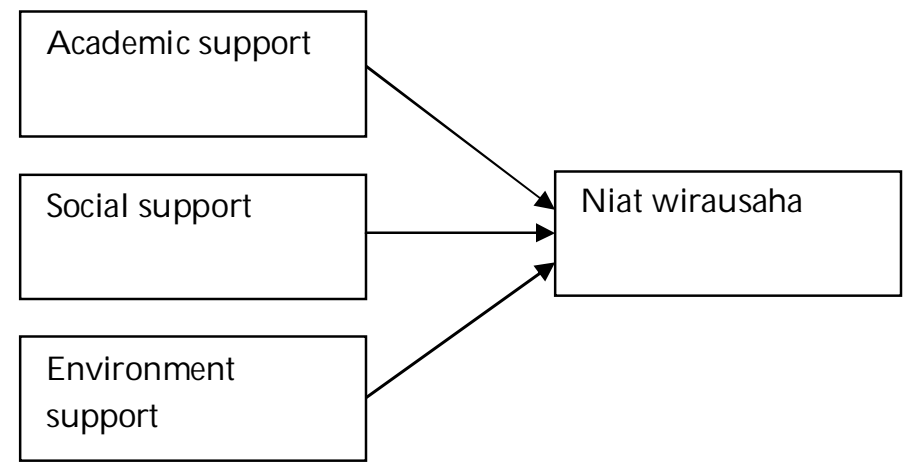

Gambar 1. Model penelitian

\section{Metode Penelitian}

\section{Prosedur sampel dan pengumpulan data}

Sampel penelitian terdiri dari 100 mahasiswa Fakultas Ekonomi dan Bisnis Islam (FEBI) IAIN Lhokseumawe. Data dikumpulkan melalui kuesioner online. Di awal kuesioner, pernyataan menguraikan instruksi, tujuan dan sifat penelitian dan menjelaskan bahwa melanjutkan dengan kuesioner menghasilkan peserta memberikan persetujuan untuk memiliki data mereka digunakan dalam penelitian. 
Fauzani, F \& Suryani, S., N iat wirausaha, dukungan akademik, sosial dan lingkungan...

\section{Pengukuran Variabel}

Pengukuran variabel mengadaptasi penelitian sebelumnya, yaitu niat wirausaha diadaptasi skala enam item yang dikembangkan oleh Liñan dan Chen (2009). Semua item diukur menggunakan skala Likert 5 poin dengan opsi respons mulai dari 1 (sangat tidak setuju) hingga 5 (sangat setuju). Item-item contoh termasuk "Saya siap melakukan apa saja untuk menjadi wirausaha," "Tujuan profesional saya adalah menjadi wirausaha" dan "Saya akan melakukan segala upaya untuk memulai dan menjalankan perusahaan saya sendiri.

Academic support, social support dan environment support diukur dengan mengadaptasi kuesioner yang dikembangkan oleh Saeed et al. (2015). Skala multi-dimensi menilai tiga jenis dukungan untuk kewirausahaan yang diberikan oleh universitas, sosial dan lingkungan yaitu: dukungan pendidikan yang dirasakan, dukungan pengembangan konsep yang dirasakan, dan dukungan pengembangan usaha yang dirasakan. Semua item diukur menggunakan skala Likert 5 poin dengan opsi respons mulai dari 1 (sangat tidak setuju) hingga 7 (sangat setuju). Contoh item termasuk "Kampus saya menawarkan kursus elektif tentang kewirausahaan" dan "kampus saya menawarkan magang yang berfokus pada kewirausahaan.

\section{Teknik analisis}

Regresi lininer berganda digunakan untuk menguji peran variabel bebas terhadap perubahan variabel terikat (Suryani dan Hendryadi, 2018). Analisis dibentuk dalam persamaan sebagai berikut:

$Y=a+b_{1} X_{1}+b_{2} X_{2}+b_{3} X_{3} e$

Dimana,

$\mathrm{a}=$ konstanta

$b_{1-3}=$ koefisien regresi

$\mathrm{X}_{1-3}=$ variabel bebas (academic, social dan environment support)

\section{Hasil dan Diskusi}

\section{Evaluasi model}

Berdasarkan hasil perhitungan didapatkan $\mathrm{F}$ hitung sebesar 57.344 dengan tingkat signifikan 0,00 , sedangkan nilai Ftabel berlaku rumus $(k ; n-k)$ dimana $k=3$ dan $n=100$, maka menghasilkan angka $(3 ; 100-3)=\left(3\right.$ : 97) maka $F_{\text {tabe }}=2,70$. Berdasarkan $F_{\text {tabel }}$ yang diperoleh yaitu 2,70 , maka $\mathrm{F}_{\text {hitung }}>\mathrm{F}_{\text {tabel, }}$ yaitu $57.344>2,70$. Dapat dinyatakan bahwa model regresi yang digunakan sudah memenuhi syarat goodness of fit.

\section{Persamaan Regresi}

Selanjutnya evaluasi model parsial dilakukan untuk mengetahui apakah variabel bebas berpengaruh positif terhadap variabel terikat yang dilihat dari hasil regresi linier berganda. Uji secara parsial dilakukan untuk mengetahui apakah variabel bebas berpengaruh positif terhadap variabel terikat yang dilihat dari hasil regresi linier berganda. Model regresi linear berganda dengan rumus sebagai berikut:

$$
Y=8.838+0.216 X_{1}+0,264 X_{2}+0,375 X_{3}
$$


Tabel 1. Hasil regresi

\begin{tabular}{|c|c|c|c|c|c|}
\hline Variabel & B & Std. Error & Beta & $\mathrm{t}$ & Sig. \\
\hline A cademic support & .216 & .092 & .266 & 2.359 & .020 \\
\hline Social Support & .264 & .120 & .242 & 2.187 & .03 \\
\hline Lingkungan & .375 & .136 & .349 & 2.758 & \\
\hline
\end{tabular}

Sumber: data diolah (2019)

Berdasarkan hasil perhitungan di atas, maka dapat diketahui bahwa seluruh variabel bebas mempengaruhi variabel terikat yaitu variabel faktor academic support, Social Support dan lingkungan dengan di dapatkannya nilat thitung $>t_{\text {tabel }}$ yang positif dan nilai probabilitas singnifikan < dari 0,05 dan positif.

\section{Pembahasan}

Secara umum, penelitian ini menunjukkan bahwa niat kewirausahaan mahasiswa secara positif dipengaruhi oleh sejauh mana mereka merasakan dukungan akademik, sosial dan lingkungan. Pertama, academic support terbukti memiliki pengaruh positif dan signifikan terhadap niat wirausaha mahasiswa. Nilai koefisien regresi Academic support dari dalam sebesar 0,216 . Hal ini menunjukkan bahwa peningkatan pada dukungan akademik akan berdampak pula pada peningkatan niat wirausaha mahasiswa. Hasil ini mendukung temuan Smith et al (2006); Saeed et al. (2015); Suharti dan Sirine (2012); dan Mustafa et al. (2016). Artinya, persepsi positif siswa tentang dukungan akademik dapat memberikan siswa pengetahuan, keterampilan, atau teknik bisnis yang diperlukan untuk memungkinkan mereka memanfaatkan impian wirausaha mereka. Aspek A cademic support merupakan kebebasan yang dimiliki oleh anggota sivitas akademika untuk melaksanakan kegiatan yang terkait dengan pendidikan dan pengembangan ilmu pengetahuan dan teknologi secara bertanggungjawab dan mandiri, adanya peraturan tentang kebebasan akademik merupakan implementasi bentuk dukungan akademik pada mahasiswa.

Kedua, dukungan sosial terbukti berpengaruh positif dan signifikan terhadap niat wirausaha. Nilai koefisien regresi Social Support sebesar 0,264. Hal ini menunjukkan bahwa setiap peningkatan dukungan sosial maka akan berdampak pada peningkatan niat wirausaha. Temuan ini mendukung model Luthje and Franke's model (LFM) yang memasukkan faktor lingkungan sebagai faktor penting pada wirausaha mereka (Luthje dan Franke, 2003). Hasil penelitian ini sejalan dengan Mustikawati dan Bachtiar (2008) dan Suharti dan Sirine (2012) yang membuktikan hubungan antara dukungan sosial terhadap niat wirausaha mahasiswa. Dukungan sosial baik dari teman, maupun keluarga merupakan faktor penting untuk mendorong minat siswa untuk berwirausaha. Tanpa didukung oleh orang-orang di sekitarnya, mahasi swa akan cenderung ragu untuk mengambil keputusan wirausaha. Social support/ Dukungan sosial merupakan kepercayaan dan ekspetasi seseorang bahwa ia akan mendapatkan dukungan untuk memulai sebuah bisnis baru dari kerabat dekat "belonging group" (orangtua, saudara kandung dan pasangannya) dan dari kelompok "reference" seperti teman, kolega dan dosen.

Terakhir, lingkungan memainkan peranan paling penting dalam mempengaruhi niat wirausaha mahasiswa. Nilai koefisien regresi lingkungan sebesar 0,375. Hal ini menunjukkan bahwa setiap peningkatan pada dukungan lingkungan, maka akan meningkatkan niat wirausaha mahasiswa. Hal ini menunjukkan bahwa antara lingkungan dan ketertarikan mahasiswa untuk berwirausaha menunjukkan hubungan yang positif. Seperti dukungan sosial, bukti empiris mengenai hubungan lingkungan dengan niat wirausaha ini juga mengkonfirmasi Luthje and 
Fauzani, F \& Suryani, S., N iat wirausaha, dukungan akademik, sosial dan lingkungan...

Franke's model (LFM). A spek lingkungan juga tidak bisa dipungkiri akan pengaruhnya terhadap berwirausaha masyarakat karena Lingkungan adalah kelompok masyarakat yang sehari-harinya berjumpa baik lingkungan keluarga, lingkungan tempat tinggal maupun sekolah, jika lingkungannya dilihat dan dirasakan menarik dalam berwirausaha, maka masyarakat dalam kelompok juga akan lebih suka untuk berwirausaha karena hasil yang diperol eh dirasakan dapat memenuhi kebutuhannya.

\section{Kesimpulan}

Pengembangan kewirausahaan merupakan salah satu kunci keberhasilan ekonomi di sebuah negara. Dalam konteks ini, Perguruan tinggi di Indonesia harus dapat berperan lebih masif sebagai lembaga pendidikan tinggi yang memiliki infrastruktur dan pengetahuan yang diperlukan untuk ini. Hasil penelitian ini menunjukkan bahwa niat kewirausahaan mahasiswa untuk menciptakan bisnis sangat ditentukan terutama dari lingkungan, dukungan sosial dan akademik.

\section{Implikasi praktis}

Hasil studi ini mengkonfirmasi bahwa lingkungan memainkan peran paling dominan dalam mempengaruhi niat wirausaha. Lingkungan disini berarti situasi dimana mahasiswa sehari-hari tinggal dan bersifat tetap, misalnya latar belakang pekerjaan orang tua, keluarga dan teman. Mahasiswa yang berada di lingkungan pekerja akan punya kecenderungan untuk menjadi pekerja, dibandingkan berwirausaha. Untuk mengatasi hal ini maka pihak perguruan tinggi perlu memberikan pemahaman kepada pihak keluarga melalui pertemuan-pertemuan formal sehingga selain dapat menciptakan dukungan sosial dari keluarga, juga dapat memberikan pemahaman yang lebih luas kepada masyarakat mengenai pentingnya wirausaha. Implikasi kedua adalah untuk mendorong niat wirausaha dari sisi akademik, pihak perguruan tinggi perlu meningkatkan mutu pendidikan wirausaha dengan memberikan serangkaian praktik langsung (mengurangi teori), melaksanakan program pelatihan dan praktik wirausaha melalui program magang, menyediakan lab dan inkubasi bisnis bagi mahasiswa sehingga dorongan untuk menjadi wirausaha semakin tinggi.

\section{Keterbatasan}

Penelitian ini hanya dilakukan di salah satu perguruan tinggi sehingga memiliki keterbatasan gernalisasi. Selain itu, faktor yang diidentifikasi dalam penelitian ini tidak mempertimbangkan faktor personal mahasiswa seperti yang disarankan pada model Luthje and Franke's model (LFM). Penelitian berikutnya disarankan untuk memperluas sampel ke berbagai perguruan tinggi, menambah faktor personal seperti demografik dan kepribadian untuk memperluas model penelitian.

\section{Daftar Pustaka}

Azwar, B. (2013). Analisis Faktor-faktor yang Mempengaruhi Niat Kewirausahaan (Entrepreneurial Intention)(Studi Terhadap Mahasiswa Universitas Islam Negeri SUSKA Riau). M enara, 12(1), 1222.

Bhandari, N. C. (2006). Intention for entrepreneurship among students in India. The Journal of Entrepreneurship, 15(2), 169-179.

Barba-Sánchez, V., \& Atienza-Sahuquillo, C. (2018). Entrepreneurial intention among engineering students: The role of entrepreneurship education. European Research on $M$ anagement and Business Economics, 24(1), 53-61. 
Block, J. H., Thurik, R., \& Zhou, H. (2013). What turns knowledge into innovative products? The role of entrepreneurship and knowledge spillovers. Journal of Evolutionary Economics, 23(4), 693-718.

Colette, H. F. Hill, Leitch, C. (2005). Entrepreneurship education and training: Can entrepreneurship be taught?. Education + Training, 47 (3) (2005), pp. 158-169

Gelaidan, H. M., \& Abdullateef, A. O. (2017). Entrepreneurial intentions of business students in Malaysia: the role of self-confidence, educational and relation support. Journal of Small Business and Enterprise D evelopment, 24(1), 54-67.

Lüthje, C., \& Franke, N. (2003). The 'making' of an entrepreneur: testing a model of entrepreneurial intent among engineering students at MIT. R\&d M anagement, 33(2), 135-147.

Maresch, D., Harms, R., Kailer, N., \& Wimmer-Wurm, B. (2016). The impact of entrepreneurship education on the entrepreneurial intention of students in science and engineering versus business studies university programs. Technological forecasting and social change, 104, 172-179.

Mustafa, M. J., Hernandez, E., Mahon, C., \& Chee, L. K. (2016). Entrepreneurial intentions of university students in an emerging economy: The influence of university support and proactive personality on students' entrepreneurial intention. Journal of Entrepreneurship in Emerging Economies, 8(2), 162-179.

Mustikawati, I., \& Bachtiar, M. (2008). Hubungan Antar Dukungan Sosial (Orang Tua) Dengan Minat Berwirausaha Pada Siswa Sekolah Menenga Kejuruan. Fakultas Psikologi dan IImu Sosial Budaya. Yogyakarta: Universitas Islam Indonesia

Oosterbeek, H., Van Praag, M., \& Ijsselstein, A. (2010). The impact of entrepreneurship education on entrepreneurship skills and motivation. European economic review, 54(3), 442-454.

Rahmah, Y. F. (2017). Entrepreneurial Education Dan Entrepreneurial Intention: Social Support Sebagai Moderasi Variabel. JISP O : Jurnal IImu Sosial dan IImu Politik, 7(1), 74-82.

Saeed, S., Yousafzai, S. Y., Yani-De-Soriano, M., \& Muffatto, M. (2015). The role of perceived university support in the formation of students' entrepreneurial intention. Journal of Small Business M anagement, Vol. 53 No. 4, pp. 1127-1145.

Smith, A. J., Collins, L. A., \& Hannon, P. D. (2006). Embedding new entrepreneurship programmes in UK higher education institutions: challenges and considerations. Education + training, 48(8/9), 555-567.

Souitaris, V., Zerbinati, S., \& Al-Laham, A. (2007). Do entrepreneurship programmes raise entrepreneurial intention of science and engineering students? The effect of learning, inspiration and resources. Journal of Business venturing, 22(4), 566-591.

Suharti, L., \& Sirine, H. (2012). Faktor-faktor yang berpengaruh terhadap niat kewirausahaan (entrepreneurial intention). Jurnal manajemen dan kewirausahaan, 13(2), 124-134.

Suryani \& Hendryadi. (2018). Metode Riset Kuantitatif. Jakarta: Prenadamedia Group

Von Graevenitz, G., Harhoff, D., \& Weber, R. (2010). The effects of entrepreneurship education. Journal of Economic Behavior \& Organization, 76(1), 90-112.

\section{A bout Authors}

Fauzani dan Dr. Suryani, M.Si adalah mahasiswa dan dosen di Fakultas Ekonomi dan Bisnis Islam Jurusan Ekonomi Islam, IAIN Lhokseumawe. Korespondensi dapat dilakukan melalui email: suryapijar@yahoo.com

Accepted author version posted online: 30 Dec 2019

$$
\text { (c) (1) }
$$

(C) 2019 The Author(s). This open access article is distributed under a Creative Commons Attribution (CC-BY) 4.0 license 